\title{
THE SILTING-UP PREVENTION IN THE GEOTHERMAL ABSORBENT OPENINGS OF GEOTHERMAL ENERGY PLANT PYRZYCE
}

\author{
Bogdan Noga ${ }^{* 1,2}$, Jan Marjanowski ${ }^{3}$, Henryk Biernat ${ }^{1}$, Stanisław Kulik ${ }^{4}$, \\ Bogusław Zieliński ${ }^{4}$, Arkadiusz Nalikowski ${ }^{3}$ \\ ${ }^{1}$ Przedsiębiorstwo Geologiczne POLGEOL S.A., Berezyńska 39 Street, 03-908 Warszawa, Poland \\ ${ }^{2}$ University of Technology and Humanities K. Pułaski in Radom, Institute of Applied Mechanics \\ and Energy, Krasickiego 54 Street, 26-600 Radom, Poland \\ ${ }^{3}$ Przedsiębiorstwo MARCOR, Lęborska 9 Street, 80-386 Gdańsk, Poland \\ ${ }^{4}$ GEOTERMIA PYRZYCE Sp. z o.o., Ciepłownicza 27 Street, 74-200 Pyrzyce, Poland
}

\begin{abstract}
The paper presents precipitation results from cold thermal water deposits that are the main cause of clogging in absorbent geothermal wells and borehole areas. As a result of physical and chemical analysis, laboratory tests and observation of the operation of a geothermal installation, a new method was developed to prevent the precipitation of sludge from cooled thermal water. The method being a modification of soft acidising was tentatively named as a super soft acidising method.
\end{abstract}

Keywords: geothermal energy, absorption openings, silting-up, soft acidising, super soft acidising

\section{INTRODUCTION}

Poland is a country with large potential opportunities for acquiring renewable heat, with thermal waters as its carrier. More than two thirds of our country is covered by Polish lowland where thermal waters are mainly in the Lower Cretaceous and Lower Jurassic. The geothermal heating plant in Pyrzyce is located in Polish Lowland and was launched in 1997.

The technological process in a geothermal plant in Pyrzyce is to extract the thermal water, whose temperature on the earth's surface is $61^{\circ} \mathrm{C}$. The hot water is extracted from the lower Jurassic through two wells Pyrzyce GT-1 and Pyrzyce GT-3, whose depth is respectively $1637 \mathrm{~m}$ and $1630 \mathrm{~m}$ (Fig. 1). Then the water is pumped into the geothermal plant's warehouse. Maximum capacity of one borehole is up to $170 \mathrm{~m}^{3} / \mathrm{h}$ (Bujakowska et al., 1995), and the efficiency of the submersible pumps is adjusted to the possibility of the injection by means of injection wells Pyrzyce GT-2 and Pyrzyce GT-4. In Geothermal Energy Plant in Pyrzyce the distance between the boreholes and the absorbent holes is about $1600 \mathrm{~m}$.

The basic problem of almost all geothermal plants, using heat and thermal waters is a gradual decrease in the absorption reservoir layer taken from the absorbent holes (Parecki \& Biernat, 2007; Biernat et al., 2009). Putting the cooled thermal water into carbonate slot type reservoir rocks poses much less of a hassle than injection into a porous sandstone rocks, which takes place in the geothermal plant in Pyrzyce. As a result of the gradual loss of absorbance capacity the absorbent hole injection efficiency decreases, thereby the heat power of geothermal heating plant is decreasing (Biernat et al., 2010a). It

*Corresponding author, e-mail: bogdan.noga@polgeol.pl 
consists of a number of reasons, including corrosion of casing pipes (Banaś et al., 2007; Biernat et al., 2010b; Fytikas and Ungemach, 2010; Wright and Chilingarian, 1989), and most of all the silting-up of the reservoir layer (Biernat et al., 2010c; Wright and Chilingarian, 1989). As a result of progressive clogging the narrowing of the inner diameter of the absorbent hole occurs, clogging the active filters zones, ridging and reservoir rocks (Barkman and Davidson, 1972). All this leads to clogging of the pores and cracks of the aquifer level with solid particulates, and thus reduction of the absorption borehole areas and reservoir rock. The radius of borehole areas of rock permeability decreased as a result of progressive clogging can range from a few centimeters to several meters (Wright and Chilingarian, 1989).

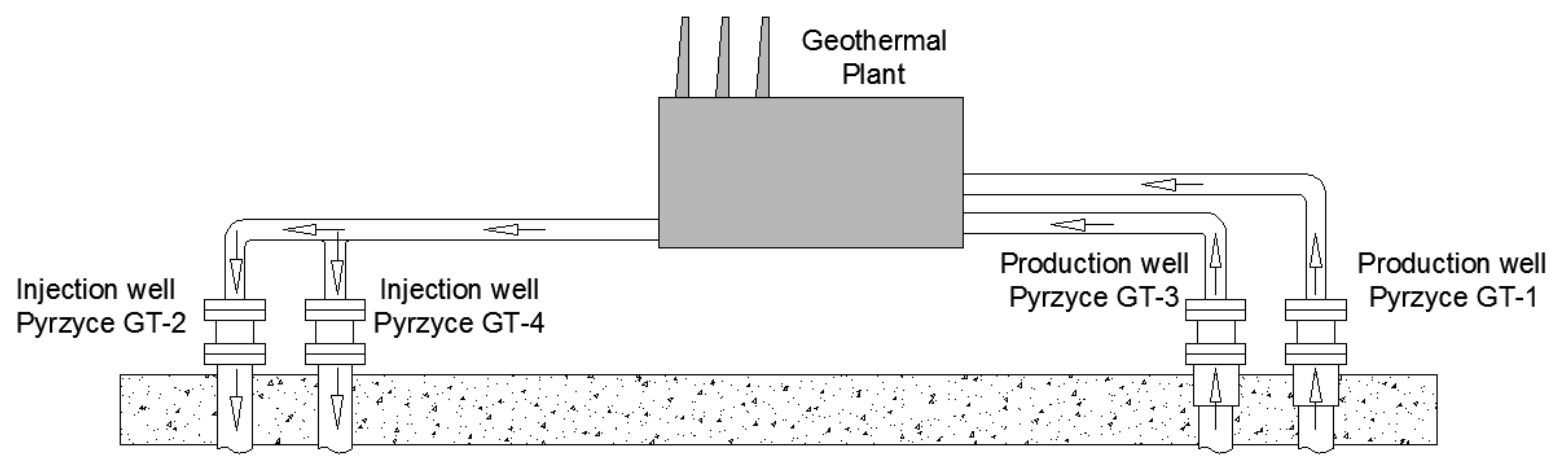

Fig. 1. Simplified diagram of geothermal water cycle in geothermal heating plant in Pyrzyce

The silting-up is now the main problem that accompanies the exploitation of thermal waters that results in reduced possibility of their injection. This phenomenon has a major impact on the operating costs for geothermal plants, and in extreme cases may require the geothermal installations to be turned off. The silting up phenomenon occurs with varying degrees in many Polish and foreign geothermal heating plants. The issues related to the effect of the precipitation of cooled thermal water is the subject of many works both on the operation as well as on the design stage and provision of the geothermal fields (Arnorsson, 2000; Biernat et al. 2010c; Biernat et al., 2011; Browne, 1984; Schröder et al., 2007; Seibt et al., 2005).

\section{IDENTIFICATION OF THE CAUSES OF THE SILTING UP}

During the cooling of thermal water in the heat exchangers physico-chemical reactions occur resulting in a secondary precipitation of chemical compounds. The silting up of the injection wells is associated with the precipitation of non-organic chemical compounds from thermal water, i.e. sparingly soluble salts and in case of oxygenation, also oxides and hydro-oxides of iron and manganese. If the oxidationreduction equilibrium is violated the precipitation of iron, manganese and copper sulfides follows. The silting up is especially intense for injection into the reservoir of the thermal water chilled in the heat process. It is the physic-chemical processes taking place in the thermal water used in energy processes that are responsible for the deterioration of the entire geothermal circulation. Reversing the direction of overlap of these processes requires intervention in conversion equilibrium taking place at the interface: liquid (thermal water), gas (released by expansion of gases from the liquid phase) and solid (precipitating deposits). This requires knowledge of the complex physico-chemical composition of the thermal water and the acid - base equilibria associated with the crystallisation of calcium carbonate, barium sulphate, strontium sulphate, and the balance in the processes of oxidation - reduction, responsible for the precipitation of oxides and sulphides of iron, copper and manganese, in the filter and the borehole zone.

Thermal water is partially decompressed on the way between the production well Pyrzyce GT-1 and injection wells Pyrzyce GT-2 and Pyrzyce GT-4. The pressure difference between the boreholes and 
absorbent holes can go up to a maximum of 1.5 bar (usually $1.0-0.5$ bar). Currently, as a result of the progressive silting up in the geothermal heating plant in Pyrzyce one of the production wells - Pyrzyce GT-3 has been excluded from the operation. There is one hole currently operating and two absorbent holes that allow to inject about $80 \mathrm{~m}^{3} / \mathrm{h}$ of chilled thermal water.

Prior to injection, cooled geothermal water is pumped through candle filters where there is a build-up of silting up products. A simplified analysis of the sediment was carried out to see the formed sediment precipitating on the candle filters with a mesh filter of 1 micron (Table 1).

Table 1. A simplistic analysis results of sediment taken from the candle filter

\begin{tabular}{|l|c|c|}
\hline \multicolumn{1}{|c|}{ Symbol } & Unit & Content \\
\hline Calcium as $\mathrm{CaO}$ & $\%$ & 1.2 \\
\hline Magnesium as $\mathrm{MgO}$ & $\%$ & 0.3 \\
\hline Iron as $\mathrm{Fe}_{2} \mathrm{O}_{3}$ & $\%$ & 76.8 \\
\hline Sulphur as $\mathrm{SO}_{3}$ & $\%$ & 8.1 \\
\hline Manganese as $\mathrm{MnO}$ & $\%$ & 6.3 \\
\hline Other compounds & $\%$ & 7.3 \\
\hline
\end{tabular}

As the analysis shows, iron is a dominant component in the sludge from the filter. It occurs in the form of brown oxide of either hydrated iron (III) $\mathrm{Fe}_{2} \mathrm{O}_{3}$ - hematite, either gray - or black FeOOH - goethite. A minor proportion of manganese in the precipitate is, present in the form of hydrated oxide, $\mathrm{MnO}$, which in the air is oxidised to black - brown hydrated oxide $\mathrm{MnO}_{2}$. In the settlement sulphates are also present. There are relatively few calcium sediments, whose share in the form of $\mathrm{CaO}$ is only $1.2 \%$. It is also important to determine the number of the remaining $7.3 \%$ of components of the sediment retained on the filter. The results of the analysis clearly indicate that the main building blocks of sediment are compounds of iron mixed with manganese and sulphates (probably strontium and barium) and a small share of ions responsible for hardness i.e. - calcium and magnesium (Marjanowski et al., 2013).

Table 2. Values of saturation indices for selected mineral compounds of thermal waters extracted from the hole Pyrzyce GT $1 /$ GT3. Pressure $\mathrm{p}=1$ bar, temperature $\mathrm{t}=61^{\circ} \mathrm{C}$

\begin{tabular}{|l|c|}
\hline \multicolumn{1}{|c|}{ Sparingly soluble compound } & $\begin{array}{c}\text { Calculated } \\
\text { saturation index }\end{array}$ \\
\hline Silica, amorphous $\mathrm{SiO}_{2}$ & 0.10 \\
\hline Strontianite $\mathrm{SrCO}_{3}$ & 0.17 \\
\hline Gypsum $\mathrm{CaSO}_{4} \times 2 \mathrm{H}_{2} \mathrm{O}$ & 0.35 \\
\hline Anhydrite $\mathrm{CaSO}_{4}$ & 0.43 \\
\hline Siderite $\mathrm{FeCO}_{3}$ & 0.45 \\
\hline Barite $\mathrm{BaSO}_{4}$ & 0.55 \\
\hline Calcite $\mathrm{CaCO}_{3}$ & 0.95 \\
\hline Dolomite $\mathrm{CaMg}_{\left(\mathrm{CO}_{3}\right)_{2}}$ & 1.23 \\
\hline Celestine $\mathrm{SrSO}_{4}$ & 2.04 \\
\hline Goethite $\mathrm{FeOOH}$ & 4.37 \\
\hline Gibbsite $\mathrm{Al}(\mathrm{OH})_{3}$ & 4.90 \\
\hline Hematite $\mathrm{Fe}_{2} \mathrm{O}_{3}$ & 3020 \\
\hline
\end{tabular}

Based on the results of physic-chemical analysis of the thermal water, the indices of sparingly soluble inorganic compounds were determined, for which there is a potential risk of precipitating with thermal water (Table 2). Saturation index for a compound is an indicator of the potential for the precipitation of 
the test compound in an aqueous solution. It is expressed as the ratio of the product of the activity of ion and anion constituting a given chemical compound and the product of solubility of the compound. Values greater than 1.0 indicate a tendency for the precipitation, but below 1.0 indicate the status of an unsaturated solution of the given compound. Index calculations were performed using specialised programs - AquaChem ${ }^{\circledR}$ and PHREEQC Interactive. The calculations referred to the parameters of pressure and temperature, corresponding to those prevailing in the geothermal plant in Pyrzyce.

When interpreting saturation indices, one should always remember that they inform how strong the tendency of the given compounds to precipitate the sediment is. However, they do not determine how much sediment precipitates down a given volume of solution. Considering the saturation values of indices the total concentration of ions that make up the compound should also be taken into account. In this case, despite the high value of the index saturation gibbsite will not be a significant threat, due to the very low levels of aluminum $\left(0.012 \mathrm{mg} / \mathrm{dm}^{3}\right)$. Even assuming the precipitation of the oxide in the form of gibbsite (which is unlikely), the maximum amount of the generated compressed sludge will amount to $0.035 \mathrm{mg}$ per 1 liter of thermal water, which gives $0.035 \mathrm{~g}$ in $1 \mathrm{~m}^{3}$. Calculating the average delivery rate of $100 \mathrm{~m}^{3} / \mathrm{h}$, gibbsite sludge could rise to about $84 \mathrm{~g} /$ day, which is a completely insignificant value in comparison to the actual precipitant amounts of sediment. Dolomite should also bring a slight contribution to the mass of sludge, and this is due to the low $\mathrm{pH}$ of the brine. Despite of the large amount of calcium and magnesium at a $\mathrm{pH}$ of 6.0 the amount of carbonate $\mathrm{CO}_{3}^{2-}$ anions will be too small to develop a large amount of dolomite. As noticed only in the case of iron oxide and strontium sulphate there is a sufficiently high saturation index and ion concentration, favouring the precipitation of relatively large amounts of sludge. Under certain conditions of pressure and temperature at the outlet of the well Pyrzyce GT-1, one must therefore expect a precipitation of significant amounts of sludge, only in the form of three compounds: celestite, goethite and hematite.

The capacity to precipitate sediments is not constant but varies dynamically during exploitation geothermal borehole, due to changes in pressure and temperature of the thermal water and fluctuations in the composition of gases in deposit (changes in the concentration of $\mathrm{CO}_{2}$ ).

The pressure drop in the flow path of the thermal water is variable in time and depends on many factors. The average decrease can, however, be assumed at 1 bar and a maximum at a level of about 1.5 bar. These figures are very significant and result in a partial expansion of the thermal water. As a result of this expansion follows the release of dissolved carbon dioxide in the thermal water. The previous studies of thermal waters, carried out also by WIOŚ in Szczecin Laboratory, showed that the concentration of dissolved carbon dioxide is $117 \mathrm{mg} \mathrm{CO} / \mathrm{dm}^{3}$, which was measured in the laboratory, in the expanded sample (at atmospheric pressure), with the cooled water and with a $p H$ of 6.4. Knowing the concentration of dissolved $\mathrm{CO}_{2}$ the $p H$ of the water sample using the well-known formula can be determined

$$
p H=-\log K_{1}+\log \left[\mathrm{HCO}_{3^{-}}\right]-\log \left[\mathrm{CO}_{2}\right]
$$

The $p H$ value for the brine solution, calculated from Eq. (1) including salinity, at the temperature of $20^{\circ} \mathrm{C}$ is 6.3 which correlates quite well with the result obtained from the measurements (6.4). At a constant temperature the gas partial pressure according to the Henry's law is described as follows

$$
p_{A}=k \cdot C_{A}
$$

By rearrangement of Eq. (2) the formula for the concentration of dissolved gas is obtained

$$
C_{A}=\frac{p_{A}}{k}
$$

which shows that at a constant temperature, dissolved gas concentration (in the liquid phase) is directly proportional to the partial pressure, $p_{A}$. 
Using the Henry's law (3) the expected concentration of $\mathrm{CO}_{2}$ in the thermal water may be calculated at different pressure values for a constant temperature. Then according to the Equation (1) the approximate $p H$ value for the thermal water can be determined. To carry out these calculations it is necessary to know the $\mathrm{CO}_{2}$ content in the exhaust geothermal borehole. Adopting the $\mathrm{CO}_{2}$ content in the range from $200 \mathrm{~g} / \mathrm{m}^{3}$ to $700 \mathrm{~g} / \mathrm{m}^{3}$, in accordance with the results of analysis carried out by the PG POLGEOL, a simulation was performed on the concentration of dissolved $\mathrm{CO}_{2}$, and the $p H$ of the thermal water at pressure ranging from 6 to 16 bar, the practical range of pressure injection into the opening absorbent hole Pyrzyce GT-2. The results of the simulation are shown in Table 3.

Table 3. Calculated values of the concentration of dissolved $\mathrm{CO}_{2}$, and the $\mathrm{pH}$ for the Pyrzyce thermal water with a temperature of $61^{\circ} \mathrm{C}$, the concentration of $\mathrm{CO}_{2}$ in the gas phase in the range $200-700 \mathrm{~g} / \mathrm{m}^{3}$

\begin{tabular}{|c|c|c|c|c|}
\hline $\begin{array}{c}\text { Brine } \\
\text { injection } \\
\text { pressure } \\
\text { [bar] }\end{array}$ & $\begin{array}{c}\text { Concentration of } \mathrm{CO}_{2} \text { in the gas phase } \\
=200 \mathrm{~g} / \mathrm{m}^{3}\end{array}$ & $\begin{array}{c}\text { Concentration of } \mathrm{CO}_{2} \text { in the gas phase } \\
=700 \mathrm{~g} / \mathrm{m}^{3}\end{array}$ \\
\cline { 2 - 5 } & $\begin{array}{c}\text { Concentration of } \\
\text { dissolved } \mathrm{CO}_{2} \\
{\left[\mathrm{mg} / \mathrm{dm}^{3}\right]}\end{array}$ & $\begin{array}{c}\text { The } p H \text { of the brine, } \\
\text { calculated according } \\
\text { to the Eq. }(1)\end{array}$ & $\begin{array}{c}\text { Concentration of } \\
\text { dissolved } \mathrm{CO}_{2} \\
{\left[\mathrm{mg} / \mathrm{dm}^{3}\right]}\end{array}$ & $\begin{array}{c}\text { The } p H \text { of the brine, } \\
\text { calculated according } \\
\text { to the Eq. }(1)\end{array}$ \\
\hline 1 & 25.41 & 6.89 & 88.93 & 6.35 \\
\hline 6 & 152.46 & 6.11 & 533.60 & 5.57 \\
\hline 7 & 177.87 & 6.05 & 622.54 & 5.51 \\
\hline 8 & 203.28 & 5.99 & 711.47 & 5.45 \\
\hline 9 & 228.69 & 5.94 & 800.40 & 5.40 \\
\hline 10 & 254.10 & 5.89 & 889.34 & 5.35 \\
\hline 11 & 279.51 & 5.85 & 978.27 & 5.31 \\
\hline 12 & 304.92 & 5.82 & 1067.20 & 5.27 \\
\hline 13 & 330.33 & 5.78 & 1156.14 & 5.24 \\
\hline 14 & 355.73 & 5.75 & 1245.07 & 5.20 \\
\hline 15 & 381.14 & 5.72 & 1334.00 & 5.16 \\
\hline 16 & 406.55 & 5.69 & 1422.94 & 5.12 \\
\hline
\end{tabular}

In the next stage an analysis was carried out the on the impact of changes in $p H$, associated with changes in pressure on the saturation indices of selected compounds that are potential sources of the sediment. The results are shown in the graph presented in Fig. 2. As may be observed with decreasing $p H$ the solubility of almost all compounds increases. At a $p H$ of 5.4 the precipitate of the sediments 4 out of the 5 test compounds cannot be expected. The only exception is strontium sulphate whose saturation index remains constant over a wide $p H$ range, indicating the possibility of precipitation of salt deposits, regardless of the reaction of thermal water. As shown in Table 3, the $p H$ of the thermal water may be associated with a specific pressure. In view of the saturation indices depending on the $p H$, a direct impact of pressure changes on the thermal water deposits of sediments is clear. For example, expansion of thermal water from a pressure of 8 bar to 7 bar will change the $p H$ from 5.45 to 5.51. With this change of the $p H$, the saturation index of hematite rises above 1 and initiates the process of sludge precipitation. Similar $p H$ ranges can be specified for other compounds: for the goethite $p H$ from 5.7 to 5.8 , for the dolomite $p H$ between 5.9 to 6.0 and the calcite $p H$ from 6.0 to 6.1 .

In the event of fluctuations in carbon dioxide content in the gas phase, these changes will also affect the concentration of dissolved $\mathrm{CO}_{2}$ in the thermal water, and thus the $\mathrm{pH}$ and solubility of resulting compounds. The reduction of the $\mathrm{CO}_{2}$ content in the gas phase from $700 \mathrm{~g} / \mathrm{m}^{3}$ to $200 \mathrm{~g} / \mathrm{m}^{3}$, while maintaining a constant pressure at 6 bar, will increase the $p H$ of the thermal water from 5.57 to 6.11 .

As temperature changes the thermodynamic parameters of the thermal water, also this parameter will exert a direct effect on the solubility of inorganic compounds. To determine the effect of temperature 
on the saturation index simulation program PHREEQC Interactive was used. The results of the simulation are shown in Fig. 3.

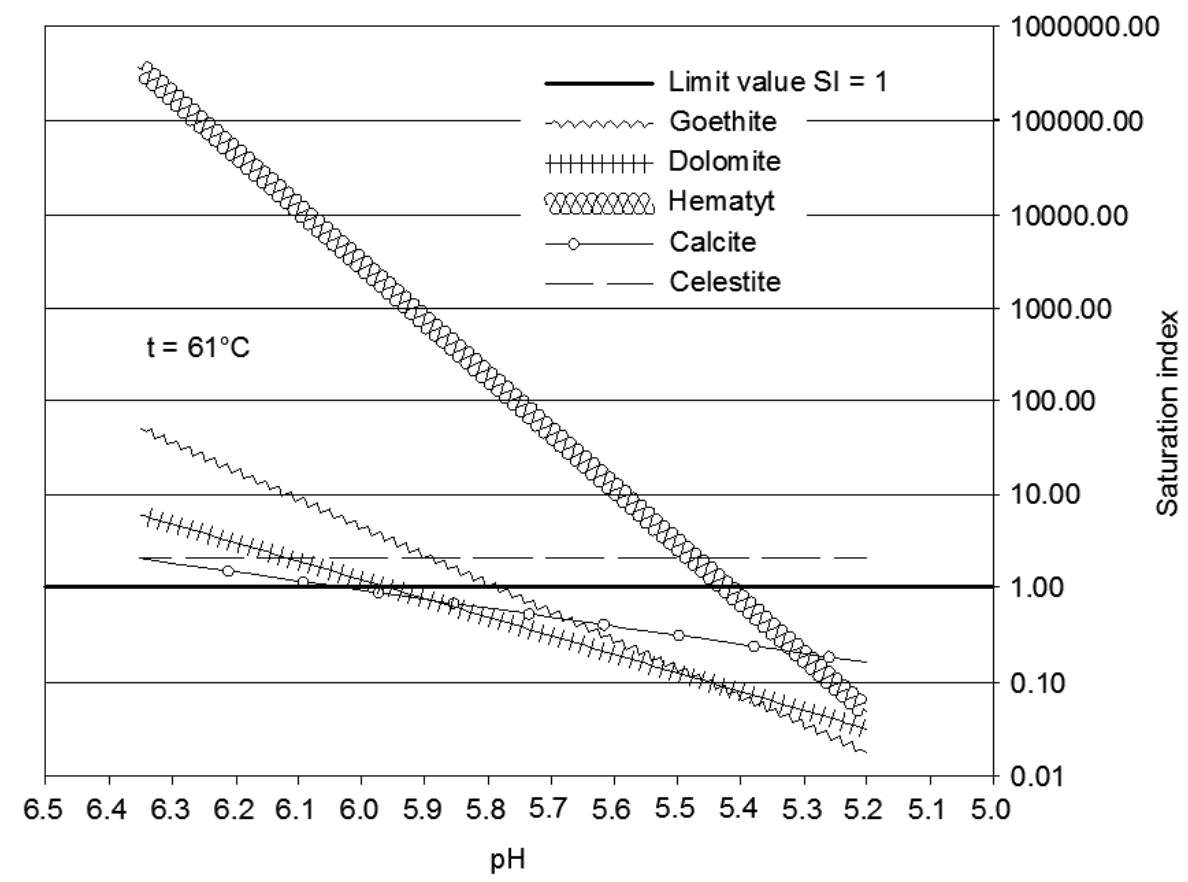

Fig. 2. Effect of the $p H$ value on the thermal water saturation indices of sparingly soluble salts and oxides

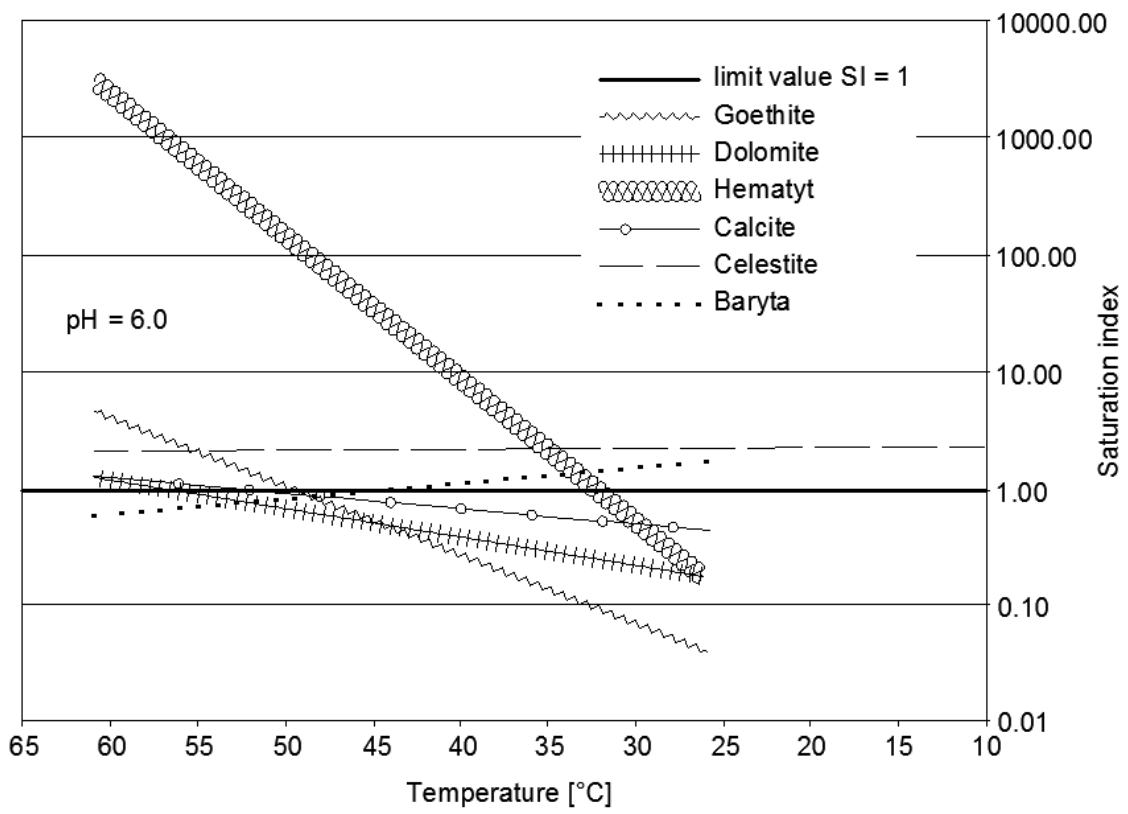

Fig. 3. Influence of temperature on the thermal water saturation indices of sparingly soluble salts and oxides

The general trend for carbonate salts and iron oxides is associated with an increase in their solubility during the cooling. The precipitation of calcite sediments, dolomite and goethite should occur below $50^{\circ} \mathrm{C}$. Inhibition of hematite seeding occurs only after the first heat exchange stage, i.e. below $35^{\circ} \mathrm{C}$, while sulphates behave differently (barites and celestite). The solubility of these compounds decreases during the cooling of the thermal water. For strontium sulphate (celestite) the effect of temperature drop is negligible, while for barium sulphate is significant enough that after cooling the thermal water below $38^{\circ} \mathrm{C}$, the process of precipitation of the salt deposits can be initiated. A potential sediment of barium 
sulfate can be expected only after the second stage of heat exchange. However, due to the low concentration of barium in thermal water (only $0.27 \mathrm{mg} / \mathrm{dm}^{3}$ ), the content of barite in the sediment should not exceed $1 \%$.

A very important element influencing the precipitation of sparingly soluble compounds is the redox potential. The thermal water from Pyrzyce has a low redox potential of $182 \mathrm{mV}$. During the extraction process, heat recovery, filtration, and then re-injecting, this potential may change significantly. The most probable change is influenced by the redox potential of the secondary thermal water oxygenation. Small amounts of oxygen can reach the thermal water as a result of ejector sucking-out sealing material leakage. An increased concentration of oxygen shifts redox potential towards higher values. To determine the impact of changes in the redox potential on the solubility of selected salts and oxides, another computer analysis was conducted. Fig. 4 shows the image of the saturation index as a function of redox potential. It can be easily noticed that the redox potential shifts towards more positive values only affects the changes in the solubility of iron oxides - goethite and hematite, but does not change the saturation indices of carbonate and sulphate salts. The increase in capacity results in a rapid decrease in the solubility of iron, which can be explained by the likely acceleration of the oxidation of iron II to iron III.

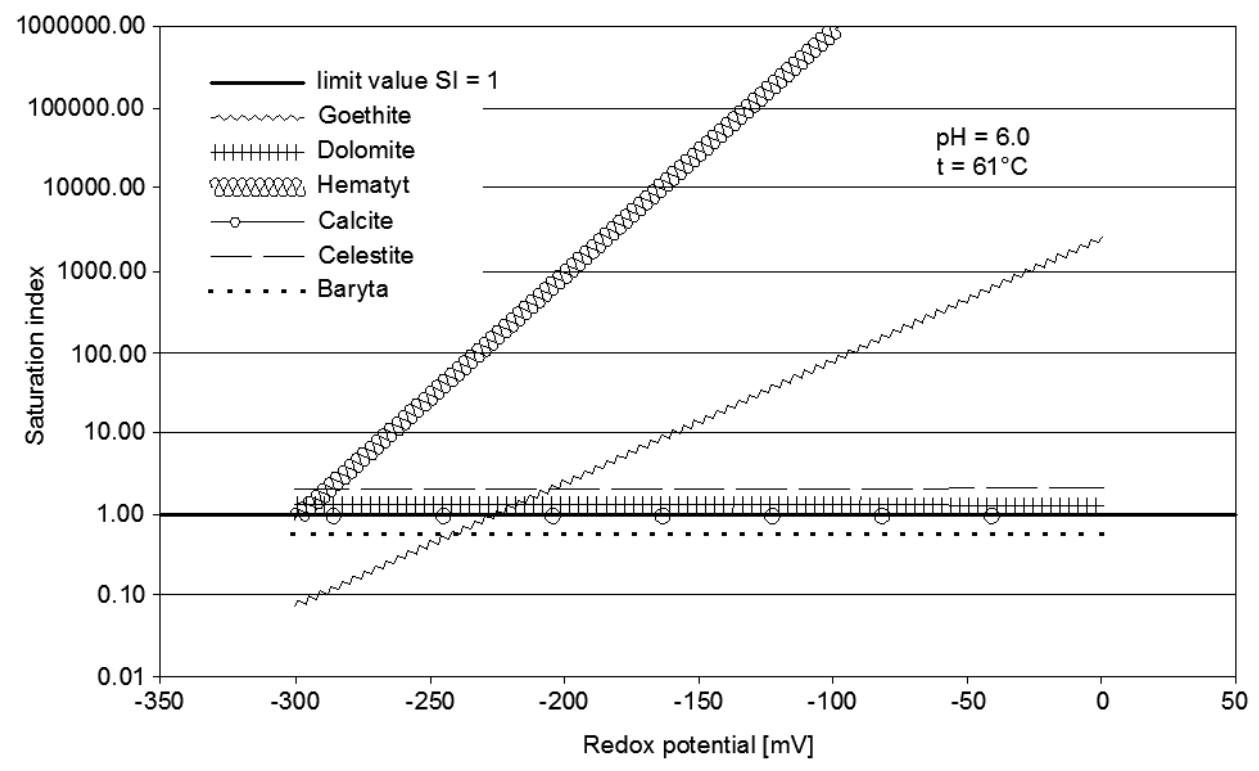

Fig. 4. Effect of redox potential of the thermal water on the saturation indices of sparingly soluble salts and oxides

\section{CONCEPT FOR PREVENTING OF SILTING UP OF ABSORBENT OPENINGS}

The effects of silting up in geothermal systems can be reduced or eliminated using appropriate methods. The choice of the appropriate method, however, is generally a quite complicated matter, since chemical, physical and mechanical methods may be used (Akar and Ignatiadis, 2005; Andritsos and Karabelas, 1991; Malate, 2003; Seibt and Wolfgramm, 2008; Ventre and Ungemach, 1998). The main methods used to prevent silting up are: mechanical removal of precipitates, maintaining stable operating conditions of thermal waters, keeping operating in a closed circuit without oxygen, dispensing small amounts of hydrochloric acid to lower the $p H$ value of the injection water, applying thermal inhibitors to prevent the deposition of secondary minerals, acidising the hole nodes. All the methods of removing the effects of silting up, both the chemical and mechanical, are relatively expensive because of the need for expensive equipment (such as an auger) and large amounts of hydrochloric acid. 
A definitely less expensive solution is to use a soft acidising method which is a modification of the traditional one using a rig. The same amount of hydrochloric acid is injected into an absorbent hole as a traditional acidising agent but in a much longer period of time (Biernat et al., 2011). The method is used in Geothermal Energy Plant Pyrzyce in the absorbent wells Pyrzyce GT-2 and Pyrzyce GT-4 and caused a reduction of the injection pressure while increasing the efficiency of the injection (Fig. 5). The resulting effect is short-term and after the procedure the injected pressure increases with a decrease in the injection rate.

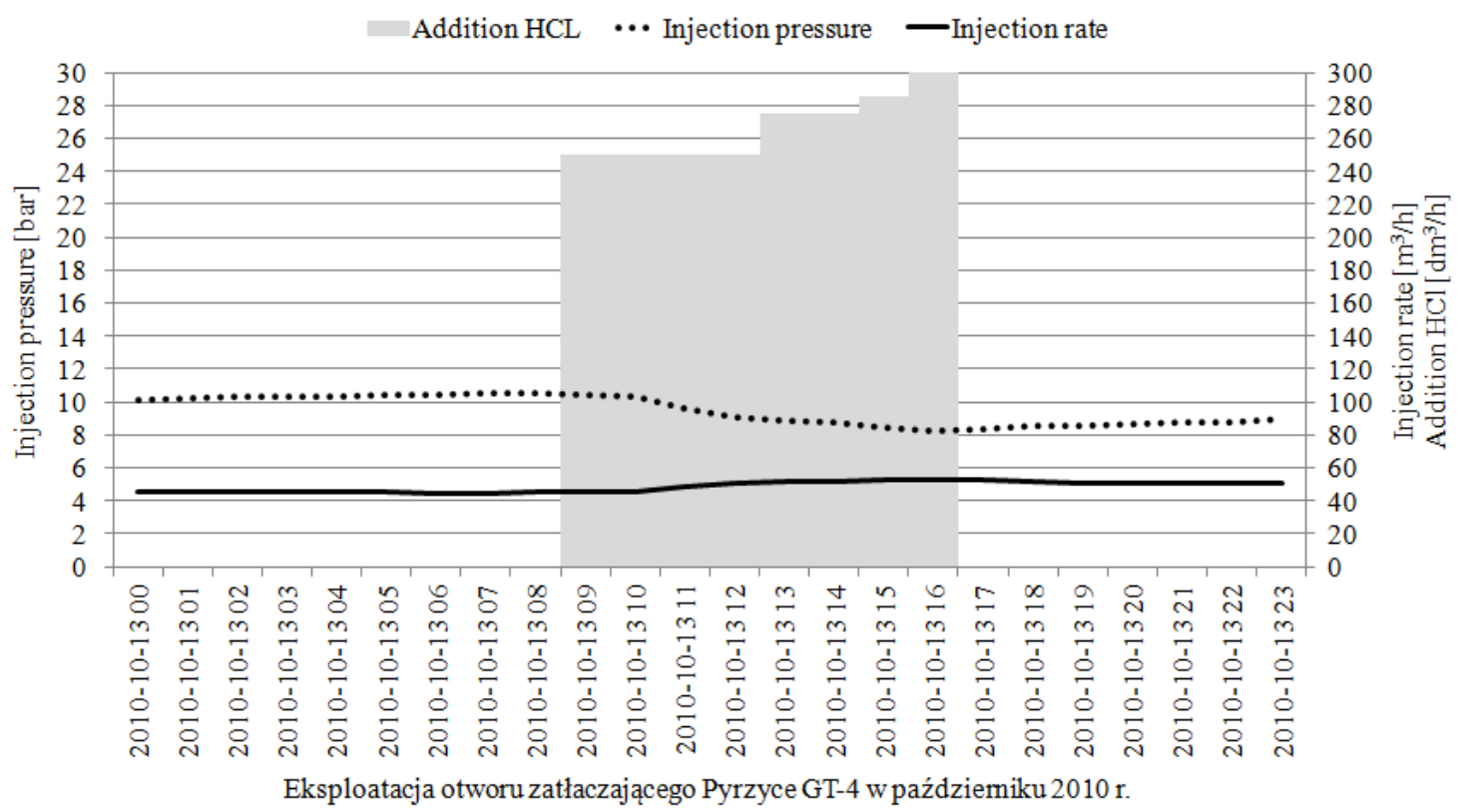

Fig. 5. The use of soft acidising in the injection opening hole Pyrzyce GT-4 in October 2010

As a result of observation and research on a method for soft acidizing it has been found out that the biodegradable dispersant has a positive effect on the elimination of salt crystallisation of calcium, magnesium, iron, manganese, copper, barium, strontium, and silica in an environment of thermal water. The above is valid only if the thermal water mineral alkalinity falls. Lowering the value of mineral basicity changes the $\mathrm{pH}$ value of the saturation indices for a number of sparingly soluble compounds below the value 1, so that the precipitation processes of sediments do not occur. Dispersant prepared with small amounts of an alkaline mineral counteracts the growth, combining and depositing of the particulate matter present in the aqueous solution, by changing the electrical charge, as a result, the particles repel each other and are not subject to agglomeration process. Dispersant allows to sustain a high degree of fragmentation (dispersion) of compounds that are precipitated out of the solution. This applies both to the sparingly soluble compounds, which are subjected to the carbonate equilibrium and those which are not subjected as gypsum, barite, celestite, crystalline and amorphous silica and fluorine compounds. Thus there is no aggregation of these particles and the formation of larger structures, and ultimately there is no sludge sedimentation.

A combination of soft acidizing and the results of the conducted research led to the development of new methods to prevent the formation of absorbent silting up in geothermal openings, which was called a super soft acidizing. It is worth mentioning here that all the previously used methods remove sediments, which are the effects of silting up. Super soft acidizing method relates to silting up prevention by influencing the chemical characteristics of the thermal water without interrupting the system operation. The preventive effect is achieved by continuous dosing of hydrochloric acid, oxygen scavenger and biodegradable dispersant (Fig. 6). The new method will keep the absorbent hole absorption constant, and thus will improve the efficiency of the geothermal heat plant. 


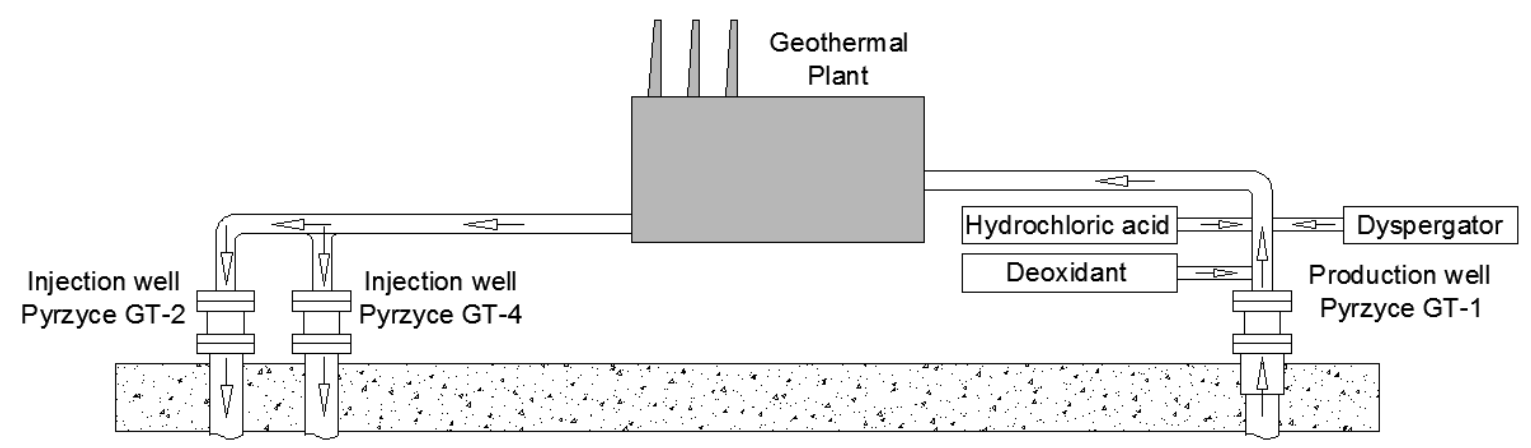

Fig. 6. Simplified diagram of the super soft acidising method

An important distinguishing feature of the super-soft acid method is the amount of hydrochloric acid which is added to the thermal water used in the process of dosing (injection). This quantity should be up to $25 \%$ of the thermal water alkalinity. As a rule, it will be even lower as a result of obtaining the proper $\mathrm{pH}$ of the thermal water, taking into account the product of solubility of the compounds easily crystallising, $p H$, redox potential, temperature, and pressure. The quantity of $\mathrm{HCl}$ necessary for a continuous dosing is determined by a team of realization based on data obtained from the pressure analysis of the injection of the cooled thermal water.

Hydrochloric acid reacts with bicarbonate with the release of carbon dioxide according to reaction (4). The separated acid in the grafting reaction of the thermal water carbon dioxide is responsible for acidification of the environment i.e. lowering the $p H$ to a desired level. When analysing the reaction (4), it can be noted that all the acid is reacted with bicarbonate salt (calcium sulphate) immediately after the injection it to the thermal water and it would not remain in the aquifer.

$$
\mathrm{HCO}_{3^{-}}+\mathrm{HCl} \rightarrow \mathrm{CO}_{2} \uparrow+\mathrm{Cl}^{-}+\mathrm{H}_{2} \mathrm{O}
$$

Because it is extremely difficult to model brine environment in a laboratory, mainly due to large changes in the concentration of $\mathrm{CO}_{2}$ in water due to thermal expansion, the final $\mathrm{pH}$ and redox potential in a system will be measured in the real life environment. The final measurement will be based on the actual analysis of the movement parameters obtained from injection well and especially on the efficiency of the injection and the absorption of the resource. In order to confirm the effectiveness of the described concept of super-soft acid treatment, the survey on the thermal water circulation in Pyrzyce Geothermal Energy Plant Research will be carried out under the EU LIFE + program.

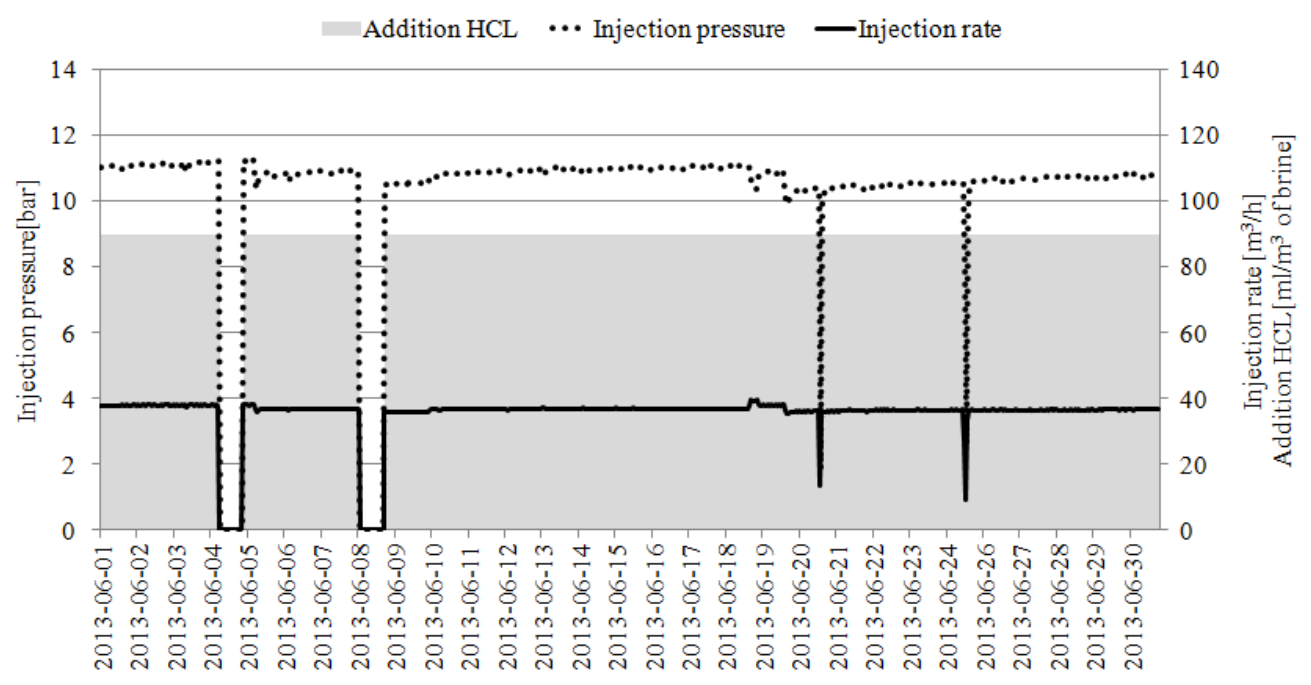

Fig. 7. The results of the super soft acidising method testing in the absorbent hole Pyrzyce GT-2 in June 2013. 
As part of the ongoing research in Geothermal Energy Plant Pyrzyce the concentration of thermal water's conditioning preparations are subjected to a continual modification. Conditioning preparations are hydrochloric acid, oxygen scavenger and dispersant, and the dosage is independent, that is, each formulation separately. After an initial test phase in June (Fig. 7) and July (Fig. 8), 2013 it can be seen that the method of super soft acidizing stabilised the geothermal system. Currently, geothermal system downtime results merely from power outages in the power grid. Restarting the geothermal system takes the parameters before the crash.

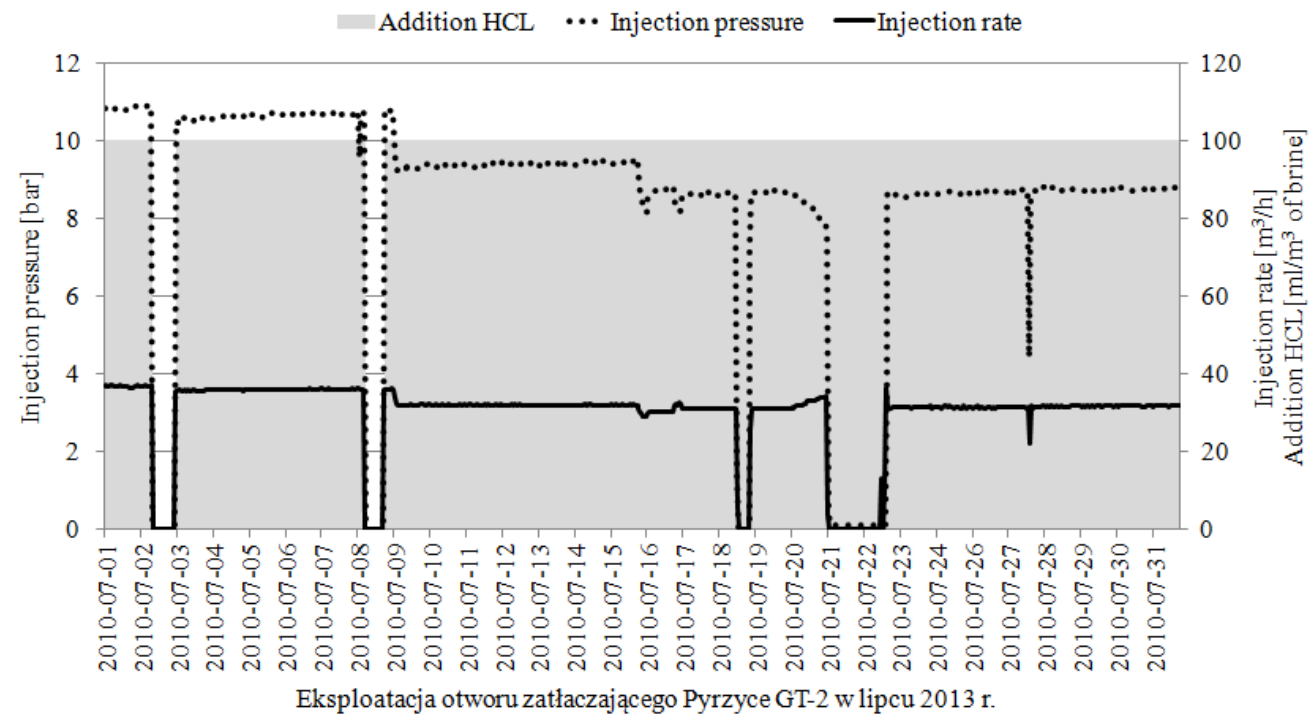

Fig. 8. The results of the super soft acidising method testing in the absorbent hole Pyrzyce GT-2 in July 2013

\section{CONCLUSIONS}

As demonstrated in the paper the largest share of deposits silting up the thermal water aquifer (zone with the hole injection) are iron compounds, mainly hematite and less of goethite. Other metal compounds can theoretically accumulate as gibbsite and celestite. The contribution of dolomite (mainly calcite) is potentially negligible, even though exceeding the solubility product twice is usually sufficient to precipitate the crystals of calcite $\mathrm{CaCO}_{3}$. Thus, the balance: compounds $\mathrm{Fe}-\mathrm{CaCO}_{3}-\mathrm{CO}_{2}$ is important especially from the point of view of maintenance of iron in the dissolved state as $\mathrm{Fe}^{+2}$ ions. Any imbalance in thermal water by changing the discharge pressure causes changes in $\mathrm{CO}_{2}$ solubility and the $\mathrm{pH}$. When oxygen will get access into the thermal water, for example due to a leakage of the overhead section (penetration of plastic, sucking on chokers), the precipitation of hematite $\mathrm{Fe}_{2} \mathrm{O}_{3}$ and/or goethite $\mathrm{FeOOH}$ starts, followed by other chemical compounds.

Reduction of $\mathrm{CO}_{2}$ concentration in the gas phase due to expansion of the thermal water increases the $p H$ and consequently soluble salts and oxides (hematite, goethite, dolomite, calcite) can be precipitated in the form of deposits, subject to compliance with other conditions of crystallisation. A low redox potential of the thermal water is disturbed due to inclusions of oxygen to the closed system of the thermal water and the redox potential begins to rise. An increase in the redox potential results in saturation index of hematite and goethite growth (following so-called logarithmic growth) and hence a sharp increase in the potential of oxide precipitates in the form of sludge. With an increase in the redox potential oxidation of iron in the oxidation state +2 and +3 oxidation state is accelerated. 
In conclusion, it must be noted that the low $p H$ and low redox potential sediments hinder the crystallization of oxides: hematite and goethite. Low $\mathrm{pH}$ also hamper the crystallization of the salts: dolomite, calcite, barite and celestinum. So low $p H$ hinders and helps keeping silting up the holes in a more efficient absorption mode.

During the research work carried out in the Geothermal Energy Plant Pyrzyce a new method was developed - super soft acidising, whose main purpose is to prevent the formation of silting up of absorbent holes. Currently the geothermal heating plant in Pyrzyce is working on using super soft acidizing method during their daily operation. Preliminary results of using the super soft method allow us to conclude that there will be further rapid deterioration of the operating parameters. The full implementation of this method still requires further industrial-scale research related to the addition of small doses of polymers and/or dispersants, which should contribute to further stabilisation of the geothermal heat plant in Pyrzyce.

\section{SYMBOLS}

$C_{A} \quad$ concentration of dissolved gas in the liquid, $\mathrm{mol} / \mathrm{dm}^{3}$

$k \quad$ Henry's constant, $\mathrm{mol} /\left(\mathrm{dm}^{3} \cdot\right.$ bar $)$

$K_{l} \quad$ constant dissociation of carbonic acid,

$\left[\mathrm{HCO}_{3^{-}}\right]$bicarbonate ion concentration, $\mathrm{mol} / \mathrm{dm}^{3}$

$\left[\mathrm{CO}_{2}\right] \quad$ concentration of dissolved carbon dioxide, $\mathrm{mol} / \mathrm{dm}^{3}$

$p_{A} \quad$ the partial pressure of the gas above the liquid, directly proportional to the total pressure, bar

\section{REFERENCES}

Akar A.A., Ignatiadis I., 2005. Modeling of deposition phenomena in low enthalpy geothermal wells. Proceedings of the World Geothermal Congress 2005. 24 - 29 April 2005, Antalya, Turkey.

Andritsos N., Karabelas A.J., 1991. Sulfide scale formation and control: The case of lead sulfide. Geothermics, 20, 343-353. DOI: 10.1016/0375- $\overline{6505(91)} \overline{90025-Q}$.

Arnorsson S. (Ed.), 2000. Isotopic and chemical techniques in geothermal exploration, development and use. Sampling methods, data handling, interpretations. International Atomic Energy Agency, Vienna.

Banaś J., Mazurkiewicz B., Solarski W., 2007. Korozja metali w wodach geotermalnych. Technika Poszukiwań Geologicznych. Geotermia, Zrównoważony Rozwój, 2, 5 - 12.

Barkman J.H., Davidson D.H., 1972. Measuring water quality and predicting well important. J. Petroleum Technology, (253) July, 865 - 873.

Biernat H., Kulik S., Noga B., 2009. Renewable energy potential and problems related with exploitation of geothermal heat plants run on water from porous collectors. Przeglad Geologiczny, 57, 655 - 656 (in Polish).

Biernat H., Kulik S., Noga B., 2010a. Problems associated with exploitation geothermal plants to use thermal water with rock pore. Geological Exploration Technology Geothermics, Sustainable Development, 1-2, 17 - 28 (in Polish).

Biernat H., Kulik S., Noga B., Kosma Z., 2010b. Problemy korozji przy zatłaczaniu wykorzystanych wód termalnych. Modelowanie Inżynierskie, 8, 13 - 18.

Biernat H., Kulik S., Noga B., Kosma Z. 2010c. Problemy inkrustacji przy zatłaczaniu wykorzystanych wód termalnych. Modelowanie Inżynierskie, 8, 7 - 12.

Biernat H., Kulik S., Noga B., Kosma Z., 2011. Próba zapobiegania kolmatacji geotermalnych otworów zatłaczających w wyniku zastosowania miękkiego kwasowania. Modelowanie Inżynierskie, 11, 67 - 74.

Browne P.R.L., 1984. Lectures on geothermal geology and petrology. UNU Geothermal Training Programe. Report 2. Reykjavik, Iceland. 
Bujakowska K., Biernat H., Bentkowski A., Kapuściński J., 1995. Dokumentacja hydrogeologiczna zasobów eksploatacyjnych ujęcia wód termalnych w utworach jury dolnej dla potrzeb m. Pyrzyce województwo Szczecińskie. Arch. PG POLGEOL, Warszawa.

Fytikas M., Ungemach P., 2010. Geothermal resource management, In: Popovski K., Andritsos N., Fytikas M., Vasilevska-Popovska S., Sanner B., Ungemach P., Koutsoukos P., Valdimarsson P. (Eds.), Geothermal energy. PLM/GEOCOM/ISS Publication, available at: www.maga.con.mk.

Malate R.C.M., 2003. Well intervention techniques. Proceedings of the International Geothermal Course. Reykjavik, Iceland, September 2003.

Marjanowski J., Biernat H., Kulik S., Nalikowski A., Noga B., Zieliński B., 3013. Problemy kolmatacji w otworach chłonnych w Geotermii Pyrzyce oraz możliwości ich zapobiegania w wyniku zastosowania metody super miękkiego kwasowania. INSTAL, 9/2013, 34 - 38.

Parecki A., Biernat H., 2007. Próba rozwiązania problemów towarzyszących eksploatacji ciepłowni geotermalnych wykorzystujących wody termalne z kolektorów porowych. Technika Poszukiwań Geologicznych. Geotermia, Zrównoważony Rozwój, 2, 107 - 110.

Schröder H., Teschner M., Köhler M., Seibt P., Krüger M., Friedrich H.J., Wolfgramm M., 2007. Long term reliability of geothermal plants - examples from Germany. Proceedings of the European Geothermal Congress 2007. Unterhaching, Germany. Paper no. 137.

Seibt P., Kabus F., Hoth P., 2005. The Neustad-Glewe Geothermal Plant - practical experience in the reinjection of cooled thermal waters into sandstone aquifers. Proceedings of the World Geothermal Congress 2005, Turkey. Paper no. 1209.

Seibt P., Wolfgramm M., 2008. Practical experience in the reinjection of thermal waters into sandstone. Proceedings of the Workshop for decision makers on direct heating use of geothermal resources in Asia. Tianjin, China, 11-18 May, 2008. Paper no. 21.

Ventre A.V., Ungemach P., 1998. Soft acidizing of damaged geothermal injection wells. Discussion of results achieved in the Paris Basin. Proceedings of the Twenty-Third Workshop on Geothermal Reservoir Engineering. Stanford University 1998.

Wirght C.C., Chilingarian G.V., 1989. Water quality for subsurface injection, In: Chilingarian G.V., Robertson J.O., Kummar S., Surface operations for petroleum production, II. Developments in Petroleum Science. Elsevier.

Received 13 February 2013

Received in revised form 25 February 2014

Accepted 26 February 2014 